\title{
Improvements in corn production technology using liquid nitrogen fertilizers
}

\author{
Vladimir Milyutkin*, Vladimir Sysoev, Oxana Blinova, Andrey Makushin, and Natalia Prazdnichkova \\ Samara State Agrarian University, 2, Uchebnaya St., 446409, Ust-Kinelskiy, Samara region, Russia
}

\begin{abstract}
The article is devoted to improvements in technology of corn production using liquid nitrogen fertilizers such as urea ammonium nitrate (UAN), in pure form UAN-32 or with the addition of sulphur $\mathrm{UAN}+\mathrm{S}$, with various methods of application before seeding or leaf-feeding dressings. This technology provides an increase in the corn yield with additional efficiency compared with the use of solid nitrogen mineral fertilizers like ammonium nitrate in conditions of insufficient moisture, which are typical of many regions of Russia and especially of the Volga region (Samara oblast).
\end{abstract}

\section{Introduction}

Due to the high nutritional and fodder characteristics of the corn agricultural crop, its production occupies a significant volume in the world, including Russia, increasing annually because of the high purchase price and the yield. At the same time, for the majority of arid regions, to which Samara oblast in the Russian Federation belongs (the place of the research), it is necessary to improve the cultivation technology of this hydrophilious crop with an increase in production efficiency primarily due to the optimal methods of using mineral fertilizers [1-6].

This situation is accompanied by the global problems of food and animal feed shortages, world's population growth, and an increase in the frequency of negative weather events, which are primarily associated with the so-called global warming [13-16].

Thus, the aim of the study was to substantiate the most effective technological methods for the corn cultivation in conditions of insufficient moisture using liquid nitrogen mineral fertilizers, such as urea ammonium nitrate (UAN), in pure form UAN-32 or with the addition of the most important and scarce chemical element sulphur UAN+S [3, 4, 6, 10-12].

\section{Material and methods}

For a number of years (2018-2020), Samara State Agrarian University has been conducting research to improve the technologies for different agricultural crop production $[3,6,10]$, including corn, taking into account the insufficient moisture in the Volga region and the projected global warming in the world. The predominant influence on the corn yields and quality of liquid nitrogen and nitrogen-sulfur-containing mineral fertilizers based on UAN-32 in comparison with solid (ammonium nitrate) is being studied. The studies used liquid nitrogen mineral fertilizers UAN-32, UAN with sulphur (S content $8 \%$ ) produced by PJSC Kuibyshev Azot on the experimental fields of Samara State Agrarian University [3].

The soil was ordinary chernozem, residualcalcareous, medium-thick, heavy loamy with a content of easily hydrolysable nitrogen, mobile phosphorus, and exchangeable potassium of $124 \mathrm{mg}, 143 \mathrm{mg}$, and $310 \mathrm{mg}$ per kg of soil, respectively, $\mathrm{pH}$ was 6.2 .

The studies were carried out in severely arid conditions in comparison with the long-term average values. So, in 2018, in April - October, only $223.3 \mathrm{~mm}$ of precipitation fell, which amounted to $72 \%$ of the average annual $308.6 \mathrm{~mm}$. Especially in terms of precipitation deficit the months May (59.8\%), June (34.2\%), August (30.2\%), September (41.7\%), and October (47.6\%) with exceeding average annual indicators in April (166.9\%) and July (144.8\%) were outstanding. In general, in Samara oblast, in terms of moisture deficit, 2018 ranked 7th since 1936. Meteorological conditions in 2019, as in 2018, were also characterized as unfavourable (arid) in relation to the average long-term regional data. In the spring-summer period of 2019, in May, precipitation fell by $7.6 \mathrm{~mm}$ more than the average annual did. In June, July, August, September, they fell, respectively, $18,34,61$ and $83 \%$ of the average annual.

The research scheme, with different doses of liquid nitrogen and nitrogen-sulphur-containing fertilizers in each variant in comparison with solid fertilizers (ammonium nitrate as a control), is shown in Table 1.

According to table, 3 periods of fertilization were provided: 1) $60 \%$ of the dose before seeding (pre-sowing treatment);2) $30 \%$ of the dose in the phase of intensive growth; 3) $10 \%$ of the dose during the formation of the crop (crop quality). Liquid fertilizers were applied by sprayers equipped with: 1) multi-jet or deflector coarsedroplet nozzles-sprayers - before seeding; 2) extension

$\overline{\text { * Corresponding author: oiapp@mail.ru }}$ 
hoses with weights - during the growing season for root application or top dressing of UAN with the exception of leaf burns.

Table 1. Terms and rates of nitrogen fertilization $(\mathrm{kg} / \mathrm{ha}$ of active ingredient).

\begin{tabular}{|c|c|c|c|c|}
\hline Terms & $\begin{array}{c}\text { Ammon. } \\
\text { nitrate, } \\
\text { N-34 }\end{array}$ & $\begin{array}{c}\text { UAN-32, } \\
\text { N-32,3 }\end{array}$ & $\begin{array}{c}\text { UAN-32, } \\
\text { N-32,3 }\end{array}$ & $\begin{array}{c}\text { UAN-32, } \\
\text { N-24 }\end{array}$ \\
\hline \multicolumn{4}{|c|}{ Corn, total nitrogen dose of $149 \mathrm{~kg} /$ ha of active ingredient } \\
\hline $\begin{array}{c}\text { Before } \\
\text { seeding }\end{array}$ & 263 & 461 & 277 & 373 \\
\hline $\begin{array}{c}\text { Stage } \\
\text { of } 3 \\
\text { leaves }\end{array}$ & 131 & - & 138 & 186 \\
\hline $\begin{array}{c}\text { Stage } \\
\text { of 8-10 } \\
\text { leaves }\end{array}$ & 44 & - & 46 & 62 \\
\hline
\end{tabular}

The research used the Mini-Till technology with a soil tillage system with disc harrows and cultivators using sprayers for liquid fertilizers UAN and chemical plant protection, fertilizer spreaders for solid mineral fertilizers and precision seeders by Eurotechnika JSC (Samara) of the German agricultural machine-building plant Amazonen-Werke (Fig. 1).

Eurotechnika JSC, with which Samara State Agrarian University has been cooperating for more than 20 years on adaptation and improvement of German equipment to regional conditions (frequent droughts), is the leading agricultural machine-building enterprise in Russia for trailed equipment.

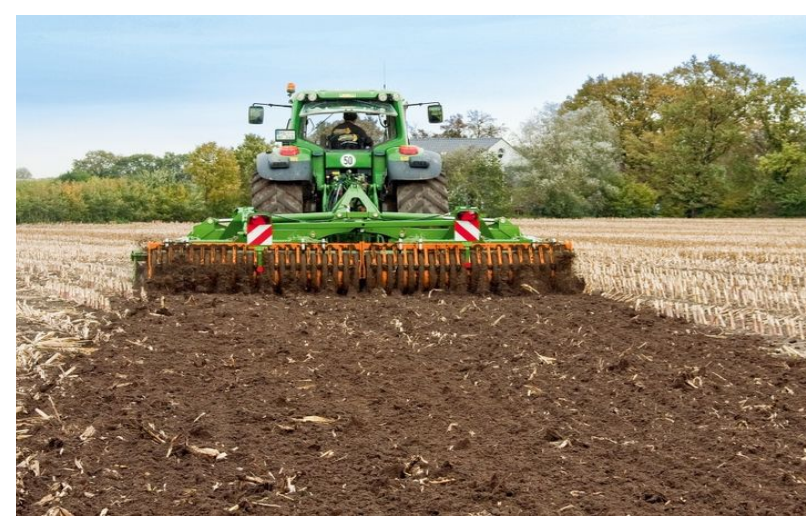

a

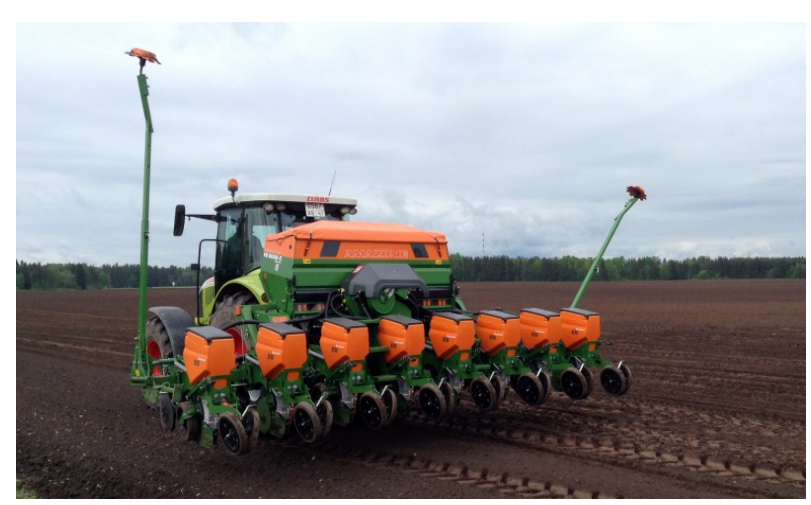

b

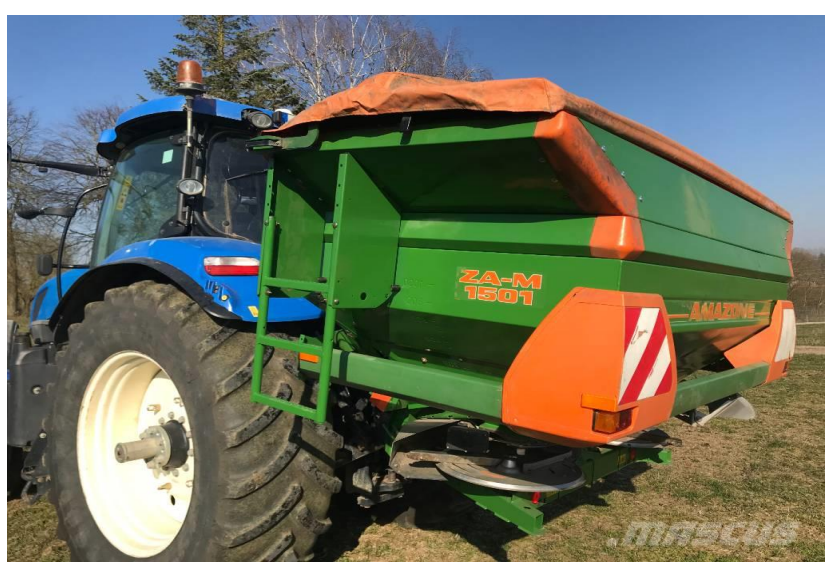

c

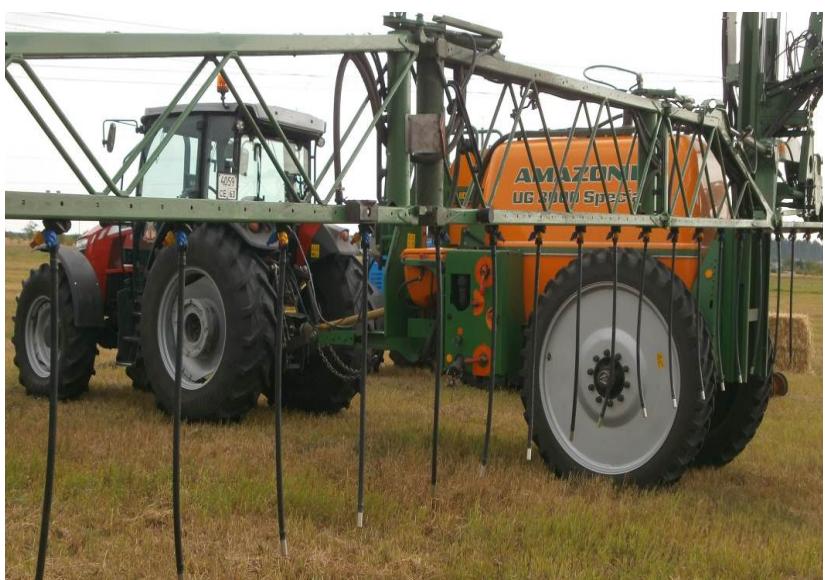

d

Fig. 1. Agricultural machines used in the research: a - disc harrow, b - precision seeder, c - spreader, d - sprayer with extension hoses.

\section{Results and discussion}

According to the results of corn production technologies (hybrids "Pioneer 7709" and NK "Falcon", Syngenta) using a system of nitrogen fertilizers, the yield and quality of corn in each experiment are provided in Table 2. A predominant increase in the yield and corn grain quality was observed with the use of liquid mineral fertilizers compared to solid ones (Table 2 and Fig. 2).

With an equal amount of nitrogen in all experiments, the highest corn yield of $84 \mathrm{c} /$ ha on average over three years of research (2018-2019 was unfavorable in terms of moisture supply compared to average long-term data) was obtained with fractional application of liquid nitrogen-sulfur-containing mineral fertilizers on base of UAN. A slightly lower yield of $82 \mathrm{c} /$ ha was obtained when using pure UAN-32 without sulfur with fractional application. With a $7 \%$ decrease, the yield of corn was obtained with a one-time (for cultivation) application of UAN-32, and the average corn yield over three years of research decreased by almost a third, $63 \mathrm{c} / \mathrm{ha}$, with the application of solid nitrogen mineral fertilizers (ammonium nitrate). 
Table 2. Corn productivity of hybrid "Pioneer 7709" (2018); hybrid NK "Falcon" (Syngenta) (2019/2020).

\begin{tabular}{|l|l|l|l|l|}
\hline Variants & $\begin{array}{l}\text { Ammonium } \\
\text { nitrate, N-90 } \\
\text { (Control) }\end{array}$ & $\begin{array}{l}\text { UAN-32, } \\
\text { N-90, before } \\
\text { seeding }\end{array}$ & $\begin{array}{l}\text { UAN-32, } \\
\text { fractionally } \\
\text { N-45; N-45 } \\
\text { before } \\
\text { seeding, } \\
\text { plant } \\
\text { dressing }\end{array}$ & $\begin{array}{l}\text { UAN-32 + S, } \\
\text { N-90 + S8 } \\
\text { before } \\
\text { seeding, } \\
\text { plant } \\
\text { dressing }\end{array}$ \\
\hline $\begin{array}{l}\text { Yield, } \\
\text { / ha }\end{array}$ & $\begin{array}{l}70.3 ; 82.3 / \\
36.7\end{array}$ & $\begin{array}{l}73.3 ; 84.6 / \\
82.1 ; 92.4 /\end{array}$ & $\begin{array}{l}82.6 ; 96.7 / \\
73.4\end{array}$ \\
\hline $\begin{array}{l}\text { Grain } \\
\text { humidity, } \\
\%\end{array}$ & $\begin{array}{l}17.2 ; 12.9 / \\
15.34\end{array}$ & $\begin{array}{l}17.2 ; 13.2 / \\
15.53\end{array}$ & $\begin{array}{l}20.8 ; 12.4 / \\
11.91\end{array}$ & $\begin{array}{l}19.0 ; 13.1 / \\
14.50\end{array}$ \\
\hline Crude ash, & $1.5 ; 1.35 /$ & $1.8 ; 1.55 /$ & $1.7 ; 1.35 /$ & $1.6 ; 1.4 /$ \\
$\%$ & 1.25 & 0.95 & 1.10 & 0.85 \\
\hline Crude \\
protein, \%
\end{tabular}

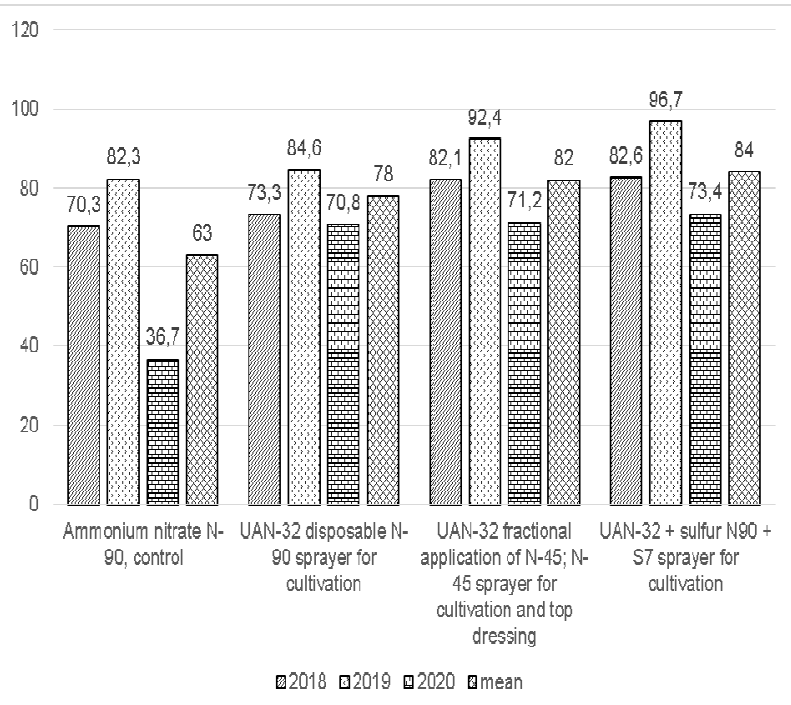

Fig. 2. Corn yield by years of research (2018-2020) in the comparative application of solid-ammonium nitrate and liquidcarbamide-ammonium mixture-UAN nitrogen fertilizers in pure form UAN-32 and with sulphur UAN+S.

The calculation of the corn production economic efficiency from the application of liquid nitrogen UAN32 and nitrogen-sulfur-containing $\mathrm{UAN}+\mathrm{S}$ mineral fertilizers compared with solid ammonium nitrate (the most common fertilizer in Russian agro-industrial complex) showed a significant advantage of liquid fertilizers, especially UAN+S (Table 3 ).

The largest additional profit when applying liquid nitrogen mineral fertilizers in comparison with the application of solid mineral fertilizers in the same nitrogen equivalent in all experiments was obtained in the variant of the fractional application of $\mathrm{UAN}+\mathrm{S}$, from 12,282 rub / ha (2018) to $47506 \mathrm{rub} /$ ha (2020). The increase in the additional profit in corn cultivation from the use of liquid nitrogen and nitrogen-sulfur-containing mineral fertilizers in comparison with solid ammonium nitrate was mainly influenced by the increased yield of corn on average over three years from 63 to $84 \mathrm{~kg} /$ ha. The significantly increased additional profit in 2020 compared to previous years (2018-2019) was associated with the purchase price, which increased from 8,500 rub / ha in 2018, 13,000 rub / ha to 35,000 rub / ha.

Table 3. Corn production economic efficiency of hybrid "Pioneer 7709" (2018); hybrid NK "Falcon" (Syngenta) $(2019 / 2020)$

\begin{tabular}{|l|l|l|l|l|}
\hline Variants & $\begin{array}{l}\text { Ammonium } \\
\text { nitrate, N- } \\
90 \\
\text { (Control) }\end{array}$ & $\begin{array}{l}\text { UAN-32, } \\
\text { N-90, } \\
\text { before } \\
\text { seeding }\end{array}$ & $\begin{array}{l}\text { UAN-32 } \\
\text { fractionally, } \\
\text { N-45; N-45 }\end{array}$ & $\begin{array}{l}\text { UAN-32 } \\
\text { S } \\
\text { fractionally, } \\
\text { N-90 + S8 }\end{array}$ \\
\hline $\begin{array}{l}\text { Costs: } \\
\text { fertilizers and } \\
\text { application, rub } \\
\text { / ha }\end{array}$ & $3464 / 3952$ & $3096 / 3352$ & $3108 / 3608$ & $2867 / 3500$ \\
\hline $\begin{array}{l}\text { Yield } \\
\text { experimental } \\
\text { plot, c / ha } \\
\text { Yield by } \\
\text { region, c / ha }\end{array}$ & $\begin{array}{l}70.3 ; 82.3 / \\
36.7\end{array}$ & $\begin{array}{l}73.3 ; 84.6 / \\
70.8\end{array}$ & $\begin{array}{l}82.1 ; 92.4 / \\
71.2\end{array}$ & $\begin{array}{l}82.6 ; 96.7 / \\
73.4\end{array}$ \\
\hline $\begin{array}{l}\text { Production } \\
\text { cost, rub / ha }\end{array}$ & $\begin{array}{l}66785 ; 69955 / \\
47710\end{array}$ & $\begin{array}{l}69635 ; 71910 / \\
92040\end{array}$ & $\begin{array}{l}77995 ; 78540 / \\
92560\end{array}$ & $\begin{array}{l}78470 ; 82195 / \\
95420\end{array}$ \\
\hline $\begin{array}{l}\text { Profitability } \\
\text { (ex. production } \\
\text { costs } \\
\text { fertilizers), rub } \\
\text { / ha }\end{array}$ & $\begin{array}{l}47821 ; 50230 / \\
27558\end{array}$ & $\begin{array}{l}51039 ; 55698 / 30 / 30 \\
72688\end{array}$ & $33.3 ; 30.0 / 30$ & $33.3 ; 30.0 / 30$ \\
\hline $\begin{array}{l}\text { Additional } \\
\text { profit } \\
\text { control, rub / ha }\end{array}$ & \multicolumn{1}{|c|}{ Price from $11 / 5 / 2019-8,500$ rub / t; from 12/01/2020 - 13,000 rub } \\
\hline
\end{tabular}

Despite the significant advantages of liquid nitrogen fertilizers based on UAN (UAN-32, UAN+S), special conditions are imposed on the application technology. Concentrated UAN-32 and UAN+S, when treating crops with nozzles, "burn" the leaves. Therefore, to prevent damage to the growing mass of corn, it is necessary to use extension hoses with weights and multi-jet nozzles at the end, for example, Lechler-Germany (Fig. 1d, 3a, b).

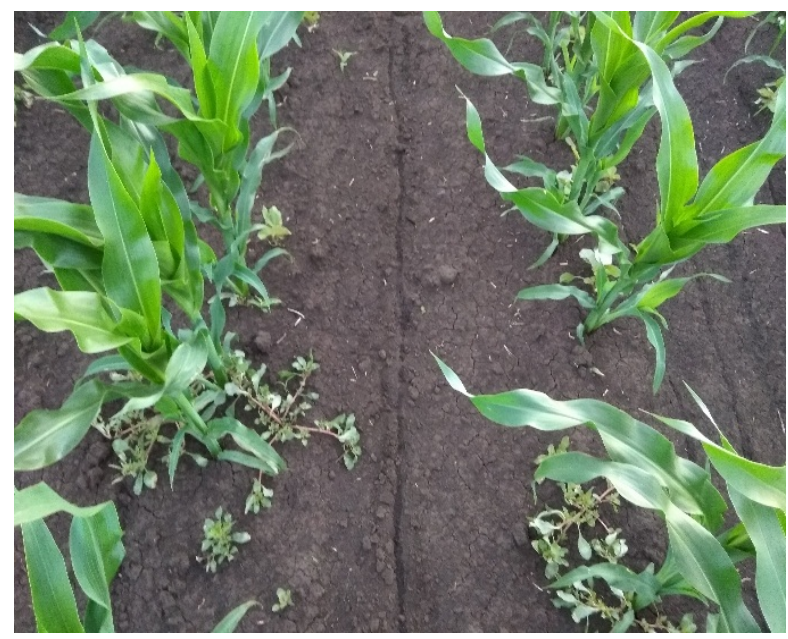

a 


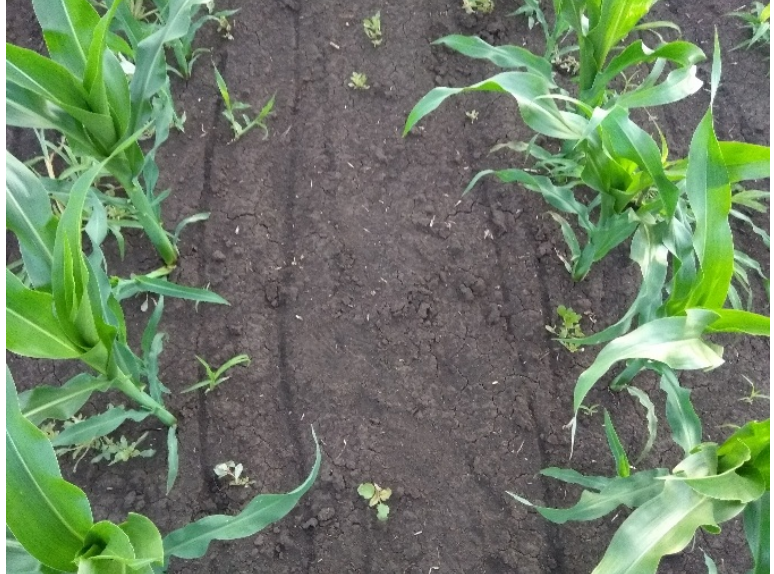

b

Fig. 3. Application of UAN-32 with extension hoses with a single-jet nozzle: $\mathrm{a}$ - in one pass, $\mathrm{b}$ - in four passes (to assess the effectiveness).

For the treatment of corn with large-drop nozzles of field sprayers, we carried out studies to substantiate the optimal concentration of the chemical solution UAN-32 and UAN-32+S, which would be safe and exclude the "burn" of corn leaves during their processing. The experiments were carried out on the same plots like the main studies. UAN-32 and UAN+S were applied with a knapsack sprayer with a coarse droplet nozzle at the rate of 35 liters of solution per 1 ha. At the same time, a safe concentration of UAN-32 and $\mathrm{UAN}+\mathrm{S}$, which was $5 \%$ of the active substance, was experimentally adopted. The treatment of corn crops was carried out in the 7-leaf phase on June 10, 2019. Visual assessment of crops showed a significant "burn" of corn leaves with concentrated fertilizers UAN-32 (Fig. 4, right) and $\mathrm{UAN}+\mathrm{S}$ (Fig. 4, left) compared to those treated with a $5 \%$ solution of UAN+S (Fig. 4 , in the center) without the "burn" of corn leaves.

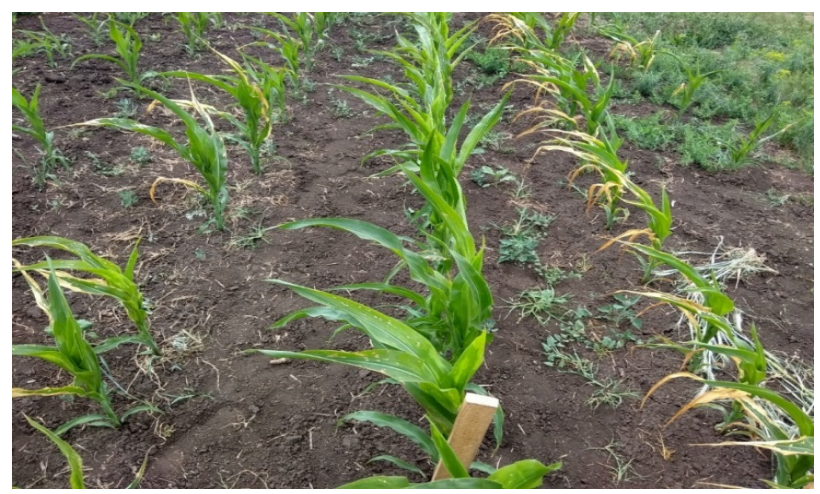

Fig. 4. Corn crops treated with concentrated UAN-32 (right), UAN-32+S (left), and 5\% solution of UAN-32 (in the center).

During the growing season, damaged corn plants treated with concentrated UAN-32 and UAN-32+S recovered, but their development was behind those treated with 5\% UAN-32 solution. Measurements of the plant height, made on 07/02/2019, showed that the average height of plants treated with $5 \%$ UAN-32 solution was $120.8 \mathrm{~cm}$ (II), treated with concentrated
UAN-32 was $93.6 \mathrm{~cm}$ (III), and with UAN-32+S was $99.6 \mathrm{~cm}$ (I) (Fig. 5). In this connection, the technological method of treating crops with a 5\% UAN solution increases the yield of corn and other row crops by 3-8\% and is safe for plants, since it does not create leaf burns.

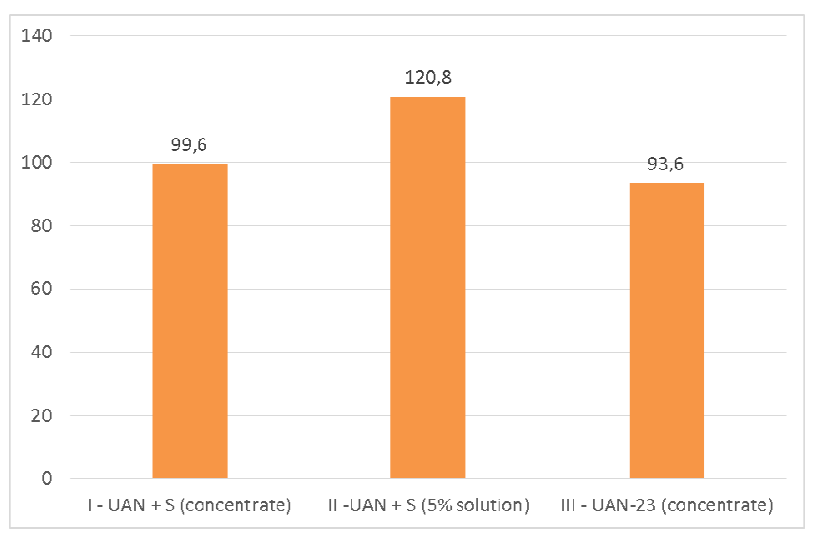

Fig. 5. Corn plant height $(\mathrm{cm})$ depending on leaf-feeding dressing with concentrated liquid mineral fertilizers UAN$32+\mathrm{S}$ (I) and UAN-32 (III) compared with 5\% solution of UAN-32 (II).

Thus, with the help of the conducted experiments, a safe concentration of liquid mineral nitrogen UAN-32 and nitrogen-sulfur-containing fertilizers $\mathrm{UAN}+\mathrm{S}$ was established, which did not cause a "burn" of corn leaves (a similar effect was obtained on sunflower and soybeans). This concentration provides the necessary feeding of corn crops with nitrogen and sulphur for a more intensive vegetation and yield increase.

\section{Conclusions}

1. Research studies carried out by Samara State Agrarian University and PJSC KuibyshevAzot in 2018-2020 confirmed the hypothesis of the effectiveness of liquid nitrogen and nitrogen-sulphur-containing mineral fertilizers based on UAN (UAN-32 and UAN+S) in the cultivation of corn in the Middle Volga region (Samara oblast). There was a stable growth trend in the variants of experiments over the years.

2. In study years with extremely unfavourable weather conditions associated with a small amount of spring-summer-autumn precipitation, the predominant efficiency of liquid mineral nitrogen and nitrogensulphur-containing fertilizers in comparison with solid ammonium nitrate was revealed in the cultivation of corn, this was especially evident in 2020.

3 . On the whole, the tendency for the yield growth according to the variants of the experiments remained unchanged for three years. On typical ordinary chernozem in the forest-steppe conditions of the Middle Volga region, in the variants of using liquid mineral fertilizers under unfavourable weather conditions for moisture in the spring-summer-autumn periods, the highest yield of corn grain ( $\mathrm{kg} / \mathrm{ha}$ ) was obtained for the years 2018-2020. Accordingly, the additional profit to control increases significantly. 
4. In addition to an increase in yield when using liquid mineral fertilizers $\mathrm{UAN}$ or $\mathrm{UAN}+\mathrm{S}$, the quality of products is improved; the costs of storage, loading and unloading of fertilizers are reduced in comparison with ammonium nitrate. Liquid fertilizers are also not dangerous goods, which is an indirect factor in increasing the efficiency of their use.

\section{References}

1. V.A. Milyutkin, V.N. Sysoev, A.P. Trots, I.N. Guzhin, S.N. Zhiltsov, Technical and technological operations for the adaptation of agriculture to global warming conditions, BIO Web of Conferences, 00075 (2020).

2. V. Buxmann, B. Meskhi, A. Mozgovoy, D. Rudoy, A. Olshevskaya, Innovative technologies and equipment from "AMAZONE" company for fertilizer application, E3S Web of Conferences, 04002 (2020).

3. E.V. Priporov, G.E. Samurganov. Analysis of the openers of grain seeders using resource-saving technology, In the book: Scientific support of the agro-industrial complex. Collection of abstracts based on the materials of the All-Russian (national) conference. Responsible for the issue A. G. Koschaev, pp. 207-208 (2019).

4. V.A. Milyutkin, N.G. Dluzhevsky, O.N. Dluzhevsky, Feasibility study of the effectiveness of liquid mineral fertilizers based on UAN-32, the feasibility and possibility of expanding their use, Agro-Forum, 2, 47-51 (2020).

5. A. Aristarkhov. Sulphur in agroecosystems of Russia: monitoring of content in soils and the effectiveness of its use, International Agricultural Journal, 5, 39-47 (2016).

6. A. Kirilesko, V. Khomina, V. Stroyanovsky, A. Chinchik, Efficiency of fertilization systems in short-term crop rotation in the Western forest-steppe of Ukraine, pp. 14-20 (02 November 2018)

7. V.A. Milyutkin, V. Buxmann, Intelligent sprayer of the new generation, Rural machinery and equipment, 7, 10-12 (2018).

8. Yu. F. Lachuga, I.V. Savchenko, P.A. Chekmarev et al., Water accumulation technologies, methods of soil cultivation and application of mineral fertilizers in extreme conditions (Ryazan, 2014).

9. V.A. Sidorova, E.E. Zhukovsky, P.V. Lekomtsev, V.V. Yakushev, Geostatistical analysis of soil and crop parameters in a field experiment on precision farming, Eurasian soil science, 8(45), 783-792 (2012).

10. D. Kurtener, V. Yakushev, E. Kruger, Kh.A. Torbert, Zoning of an agricultural field using a fuzzy indicator model, Digest: Precision Agriculture 2011 - Papers presented at the 8th European Conference on Precision Agriculture 2011, 8, 157163 (2011).

11. V.N. Bagrintseva, I.N. Ivashenenko, The influence of weather conditions in the Stavropol Territory on the effectiveness of nitrogen fertilization doses on corn, Agrochemistry, 2, 77-83 (2020).

12. V. N. Bagrintseva, V.V. Bukarev, S.V. Nikitin, M.A. Cherkasova, Efficiency of foliar feeding of corn with agrochemicals, Corn and sorghum, 2, 3-8 (2019).

13. E.V. Rudoy, M.S. Petukhova, A.F. Petrov, Crop production in Russia 2030: alternative data of the development scenarios Kapustyanchik, Data in Brief, 29, 105077 (2020).

14. L.A. Marchenko, T.V. Mochkova, V.A. Kolesnikova, Prospects for the use of liquid mineral fertilizers, in: Innovative development. Agroindustrial complex of Russia based on intelligent machine technologies: Coll. Int. scientific and technical conf., pp. 399-402 (VIM, Moscow, 2014).

15. T.V. Mochkova, T.N. Bashkirova, A.I. Kruglova, V.A. Kolesnikova, Combined use of liquid nitrogen fertilizers and pesticides - an important element of an ecologically balanced systems of cultivation of grain crops, in : Innovative development of the agroindustrial complex of Russia on the basis of intelligent machine technologies: Coll. Int. scientific and technical conf., pp. 403-405 (VIM, Moscow, 2014).

16. A.Yu. Izmailov, V.K. Khoroshenkov, Automated control system for sowing and fertilization, Agricultural machines and technologies, 4, 9-12 (2011). 